\title{
Immunomodulation in insects post-treatment with abiotic agents: A review
}

\author{
EL-SAYED H. SHAURUB \\ Department of Entomology, Faculty of Science, Cairo University, Giza 12613, Egypt; e-mail: sayedshaurub@yahoo.com
}

Key words. Insects, insecticides, chitin synthesis inhibitors, juvenile hormone analogues, inert particles, antibiotics, heavy metals, radiation, immunomodulation

\begin{abstract}
The effects of different abiotic agents that may modulate the activity of an insect's immune system are reviewed. These agents include insecticides, chitin synthesis inhibitors, juvenile hormone analogues, inert particles, antibiotics, heavy metals, radiation and miscellaneous substances. The significance of studying immunomodulation in insects treated with abiotic agents in relation to both insect control and insect-borne parasitic diseases and the link between immunomodulation in insects post-treatment with both abiotic and biotic agents are discussed.
\end{abstract}

\section{INTRODUCTION}

In contrast to vertebrates, insects lack an adaptive (acquired) immune system. They have an innate immune system that relies on germline encoded factors for recognition and killing of foreign invaders, which protects them effectively and rapidly from infection by microorganisms and parasites, many components of which are conserved in vertebrates (Gillespie et al., 1997; Vilmos \& Kurucz, 1998; Hoffmann et al., 1999; Tsakas \& Marmaras, 2010). This system is highly developed and comprises cellular and humoral components that can be activated by invasion by foreign bodies, including pathogens (Gillespie et al., 1997).

In the cellular defence mechanism, haemocytes are capable of recognizing isografts (self) and allografts (non-self). Haemocytes react in three different ways to foreign invaders: phagocytosis, nodule formation and encapsulation. These processes differ from each other primarily in the relative size of the foreign material and responding cell and the extent of the reaction (Ratcliffe \& Rowley, 1979; Wago, 1983; Götz \& Boman, 1985; Gupta, 1985; Götz, 1986; Vinson, 1990; Pathak, 1993a).

In the humoral defence mechanism there are components that are either involved in recognition or are directly responsible for the immune response. These components involve the synthesis and release of several antibacterial immune proteins. There are at least three families of antibacterial proteins: lysozymes, cecropins and attacins (Boman \& Steiner, 1981; Götz \& Boman, 1985; Boman et al., 1986; Boman \& Hultmark, 1987). Recently, Bulet \& Stöcklin (2005) classified insect antibacterial proteins in four groups; (a) cecropins, (b) cysteine-rich peptides (e.g. defensins and drosomycin), (c) proline-rich peptides (e.g. drosocins and metchnikowins) and (d) glycine-rich peptides (e.g. diptericin). The expression of this multicomponent humoral immune system requires de novo synthesis of a specific immune RNA and proteins with a broad range of antibacterial activity against Gramnegative and Gram-positive bacteria. Moreover, there are also other humoral components including lectins (haemagglutinins) and a melanin-phenoloxidase system (Pathak, 1993b; Nappi \& Sugumaran, 1993; Söderhäll \& Aspán, 1993).

Very little attention has been paid to comparing immunomodulation in insects after treatment with abiotic agents to that in insects treated with biotic agents. Therefore, this review is of the possible modulatory effects of some abiotic agents on the immune system of insects.

\section{NATURE OF ABIOTIC AGENTS INDUCING IMMUNOMODULATION IN INSECTS}

Zbinden (1987) uses the term immunomodulators to characterize a group of substances of different origin that affect the immune system, which includes: environmental chemical contaminants (pesticides, industrial emissions etc.), drugs that are manufactured using recombinant DNA and other biotechnologies, which may also contain contaminants that are sensitizing substances and physical factors (UV-B light, electromagnetic fields). Immunomodulators can either reduce the reactivity of the immune system, i.e., are immunosuppressants (Safe, 1994) or stimulate excessive reactivity, i.e., hypersensitivity (Luster \& Rosenthal, 1993). Some substances can induce the development of autoimmune diseases (Luster et al., 1996). Biological factors can also act in a broader sense as immunomodulators (Dietert et al., 1996). However, this review focuses exclusively on abiotic agents.

\section{Insecticides}

As early as 1935, Pilat studied the effect of the stomach poisons, sodium arsenite and silicofluoride on the blood of Locusta migratoria. He found that the most prominent symptoms in locusts fed on these poisons are the destruction and disintegration of their haemocytes. Yeager \& Munson (1942) also record marked haematological alterations in Spodoptera (= Prodenia) eridania poisoned with arsenicals, fluorides and mercuric chloride, whereas treatment with nicotine, rotenone and pyrethrum did not induce any haematological change. Mahmood \& Yousof 
(1985) record abnormalities in the haemocytes of Gryllus bimaculatus treated with dipterex, compared to control, including enlargement, distortion, rupture of the wall and denucleation of the haemocytes. Younes et al. (1999) record malformed haemocytes in S. exigua larvae treated with some insecticides. The blood cells appeared larger and irregular in shape compared to those in the control. Similar abnormalities are also recorded in the red cotton bug, Dysdercus koenigii, treated with the nicotinyl insecticides, acetamiprid and imidacloprid (Haq et al., 2005).

El-Sheikh (1997) found that oral administration of a $\mathrm{LC}_{50}$ dose of the pyrethroid insecticide, fenpropathrin, insignificantly increases the total and relative numbers of different haemocytes (plasmatocytes and oenocytoids) in Trogoderma granarium larvae. Although, the number of spherulocytes significantly increases and of granulocytes insignificantly decreases the number of prohaemocytes remains unchanged, compared to non-treated insects. Also, the organophosphorous (OP) insecticides, quinaphos, monocrotophos, endosulfan and dimethoate, increase the total haemocyte count (THC) in the reduviid bug, Acanthaspis pedestris. The differential haemocyte count is also affected (Ambrose \& George, 1996a, b). Differential effects of insecticides applied at different concentrations on the total and differential haemocyte counts of the reduviid bugs, Rhynocoris fuscipes, $R$. kumarii and R. marginatus are also recorded (George \& Ambrose, 1998, 2000). Treatment of D. koenigii with the nicotinyl insecticide, acetamiprid, results in an increase in THC shortly after the application of acetamiprid, followed by a decrease after half an hour and then a considerable increase again after one hour, compared to the control (Haq et al., 2005). The percentage of plasmatocytes, granulocytes and prohaemocytes decrease, whereas that of oenocytoids and spherulocytes increases, compared to the control. However, application of the nicotinyl insecticide, imidacloprid, results in a decrease in THC shortly after it is applied followed half an hour latter by an increase and another increase one hour latter. The percentages of plasmatocytes, granulocytes, oenocytoids and spherulocytes decrease, whereas that of prohaemocytes increases, compared to the control. Uckan \& Sak (2010) found that sublethal doses of the pyrethroid insecticide cypermethrin reduce the mitotic activity of haemocytes in the pupal endoparasitoid Pimpla turionellae, which parasitizes Galleria mellonella, and increase apoptosis in a dose-dependent manner. They suggest that this parasitoid may need a rich energy supply and as a consequence their defence is weakened if there is a depletion in the haemocyte count. Gad \& Abdel-Megeed (2006) show that the THC is lower in Spodoptera littoralis larvae treated with emamectin benzoate and spinosad, compared to the control. Likewise, deltamethrin (pyrethroid), chlorpyrifos (OP), spinosad and emamectin benzoate decrease the THC in Schistocerca gregaria (Halawa et al., 2007).

The main defence of insects is their haemocytes (ElKholy \& Abd El-Aziz, 2010). In this context, the foregoing findings clearly show that the THC and the percentages of the THC made up of different haemocytes are markedly affected by insecticides. Such changes might influence the activity of the immune system of insects.

Increase in the percentage of prohaemocytes after exposure to insecticides is attributed to an increase in mitosis (Jones, 1962; Mall \& Gupta, 1982). The transformation of plasmatocytes for cellular defence by loss of a portion of cytoplasm or by fragmentation or by gradual rounding off of fusciform plasmatocytes results in a reduction in the number of plasmatocytes (Gupta \& Sutherland, 1966; Beaulton \& Monpeyssin, 1976; Pathak \& Kulshreshtha, 1993). On the other hand, increase in the number of plasmatocytes is attributed to plasmatocyte differentiation of haemocytes by mitosis (Patton, 1961; Wago, 1980; Kurihara et al., 1992). Reduction in the numbers of granular haemocytes occurs due to the transformation of granular haemocytes into cystocytes or oenocytoids by extension of some cytoplasmic granules along the inner periphery of the nuclear membrane (Gupta \& Sutherland, 1966). Increase or decrease in cystocytes is reflected in the coagulation of haemolymph, since cystocytes are the effectors of coagulation (Jiravanichpaisal et al., 2006). The insecticide-induced increase in the number of oenocytoids supports their defensive function and reduction in their numbers is attributed to their transformation (Kurihara et al., 1992). The level of increase in THC reflects the level of insecticidal resistance. When insecticides reach the central nervous system a diuretic hormone is released into the haemolymph via the corpora cardiaca, which increases the rate of excretion. This results in a reduction in the volume of haemolymph, which in turn increases the THC (Lee, 1961; Patton, 1961; Pathak, $1983,1991)$. On the other hand, that the antidiuretic hormone has an antagonistic action is suggested by the decrease in the THC in insects treated with insecticides (Wheeler, 1963; Pathak, 1991).

When Drosophila melanogaster is reared on a diet containing a $\mathrm{LD}_{30}$ dose of endosulfan, the rate of encapsulation of the endoparasitoid, Leptopilina boulardi, is decreased by 26\% (Delpuech et al., 1996). In contrast, treatment with the OP insecticide primiphos-methyl results in a 1.3-fold increase in the percentage of endoparasitoids encapsulated by the Colorado potato beetle, Leptinotarsa decemlineata, on the $2^{\text {nd }}$ day post-treatment compared to the control (Dubovskiy et al., 2010). They attribute this to the effect of the insecticide on the metabolism of the insect. This result supports the earlier finding that treatment of insects with different insecticides results in the melanization of their haemolymph (Fisher \& Brady, 1980).

Landa et al. (1991) state that haemocytes of G. mellonella larvae treated with sublethal doses of an insecticide or exposed to the effects of sterile homogenates of some insect pathogens do not produce bacteriolytic proteins or synthesize less protein than the control. The authors speculate that the ability of haemocytes to induce synthesis of bacteriolytic proteins could be a reliable way of testing whether the functioning of haemocytes of insects is damaged in heavily polluted areas. Likewise, 
Jarosz \& Glinski (1999) report that the synthesis of blood lysozyme and cecropins induced by the intra-haemocoelic vaccination of $7^{\text {th }}$ instar larvae of $G$. mellonella with lipopolysaccharides (LPS) of the bacterium, Pseudomonas aeruginosa, is inhibited when they are treated with a $\mathrm{LD}_{50}$ dose of the pesticides deltamethrin (pyrethroid insecticide), trichlorfon (OP) or lindane (chlorinated hydrocarbon insecticide). The induced protective immunity in immunized larvae is attributed to a great increase in the activity of both lysozyme and cecropins, but their protection against the bacterial parasite decreases greatly when they are treated with pesticides. Brey (1994) reviews the effects of several chemical poisons on immunomodulation in insects.

Phenoloxidase (PO) (EC 1.14.18.1), a coppercontaining biofunctional enzyme, may have the same activity as tyrosinase, but is not related to it at the sequence level (Cerenius \& Söderhäll, 2004). In insects, PO is uniquely associated with three physiological important biochemical processes: sclerotization of insect cuticle, wound healing and defensive encapsulation, and melanization of foreign organisms. It catalyzes two distinct reactions of melanin synthesis-hydroxylation of monophenol (monophenolase activity) and conversion of $o$-diphenol into the corresponding $o$-quinone (diphenolase activity). The production of $o$-quinones by PO is the initial step in the biochemical cascade of sclerotization, quinine tanning and melanin biosynthesis; processes that are important in insect development and immunity (Xue et al., 2008). The effect of insecticides on PO activity of haemolymph differs from one insect species to another. Liu et al. (2009) found that the novel insecticide, butanefibronil, increases PO activity in $4^{\text {th }}$ instar larvae of the diamondback moth, Plutella xylostella, as it is 2.29 -fold higher than in the susceptible non-treated individuals. These authors also report that the resistance of treated $4^{\text {th }}$ instar larvae increases 83.8-fold compared to the susceptible strain. Furthermore, the study of Liu et al. (2010) on the effect of sublethal doses of five different insecticides on haemolymph PO activity in Tenebrio molitor larvae reveals that high concentrations of both methomyl (carbamate insecticide) and monosultap (nereistoxin insecticide) increase the PO activity, while there was no effect at low concentrations compared to the control. On the other hand, chlorpyrifos (OP) decreases PO activity; while $\beta$-cypermethrin (pyrethroid insecticide) has no effect on the PO activity.

\section{Chitin synthesis inhibitors}

Mohammed (1998) shows that $\mathrm{LC}_{50}$ levels of diflubenzuron (Dimilin) and chlorfluazuron, incorporated into the diet of $4^{\text {th }}$ instar larvae of $S$. littoralis, significantly decrease the THC and differential haemocyte counts (plasmatocytes only). Similarly, Abd El-Aziz \& Awad (2010) report that a $\mathrm{LC}_{50}$ dose of diflubenzuron, incorporated into the diet of $4^{\text {th }}$ instar larvae of Agrotis ipsilon, reduces the THC. The percentage of prohaemocytes is significantly decreased, whereas that of spherulocytes, plasmatocytes and granulocytes are significantly increased 12 and $24 \mathrm{~h}$ post-treatment. Moreover, diflu- benzuron causes ultrastructural alterations and malformations in circulating haemocytes. Prakash et al. (2007) and Pugazhvendan \& Soundararajan (2009) found that penfluron increases the THC in both D. koenigii and Chrysocoris purpureus, respectively up to $48 \mathrm{~h}$ and then it declines during the next $48 \mathrm{~h}$ after treatment, compared to the control. Penfluron inhibits chitin activity and probably functions like a toxin. This mode of action might result in a decline in THC (Lim \& Lee, 1982).

Hegazi et al. (1998) records that lefenuron has a negative effect on the encapsulation of the parasitoid Microplitis rufiventris by $S$. littoralis larvae. Treated hosts exhibit a significant reduction in either capsule thickness or encapsulation rate of the parasitoid larvae compared to control hosts. Reduced encapsulation capacity might be due to a secondary effect (s) of treatment with lefenuron, which reduces the adhesiveness of the plasmatocytes. The authors conclude that the results may be useful in improving the understanding of the insect's immune reaction and / or manipulating parasitoid activity against nonhabitual parasitoids.

It appears, therefore, that antimoulting compounds generally suppress the cellular defence mechanism in insects. This finding might indicate their possible use in insect control.

El-Moataz Bellah \& Shaurub (2000) record that last instar larvae of $S$. littoralis, just prior to pupation, that had fed on a diet containing triflumuron have significantly higher titers of lectins against both human $\left(\mathrm{O} \mathrm{Rh}^{+}\right)$ and rat erythrocytes. They also found that treatment with triflumuron did not affect the properties of lectins of $S$. littoralis larvae compared to control larvae, where lectins of both treated and control larvae were $\mathrm{Ca}^{2+}$ - and $\mathrm{Mg}^{2+}$-dependent, stabilized by the presence of disulphide bond, heat-labile and proteinaceous in nature. On the other hand, triflumuron induces new haemolymph protein bands that probably contain immune protein.

When 2-day-old larvae of the house fly, Musca domestica, are fed on a diet containing $1.1 \mathrm{ppm}$ of TH 6040 [1-(4-chlorophenyl)-3-(2, 6-diflurobenzyl)-urea] the activity of cuticle PO increases to $155 \%$ of that of the control larvae (Ishaaya $\&$ Casida, 1974). When $5^{\text {th }}$ instar larvae of Spodoptera litura are treated with two sublethal concentrations (46 mg/l and 92/l) of hexaflumuron for different periods of times, PO activity is significantly higher than in the control for each period of time and the activation rates at high concentrations are greater than at low concentrations. The PO activity in the haemolymph, cuticle and head of $5^{\text {th }}$ instar larvae increases with treatment time. The activation rate of PO for a particular treatment time is always highest in the haemolymph and lowest in the head. The PO activity recorded in prepupae and pupae that developed form $5^{\text {th }}$ instar larvae continuously treated with hexaflumuron is also significantly enhanced (Yan et al., 2010). Diflubenzuron also increases the activity of haemolymph PO in P. xylostella larvae (Liu et al., 2010).

It is well known that azadirachtin inhibits growth in insects. Treatment with azadirachtin results in a drastic reduction in THC and changes in haemocyte morphology 
leading to cell death in D. koenigii (Saxena \& Tikku, 1990), Rhodnius prolixus (Azambuja et al., 1991), Cyrtacanthacris tatarica (Peter \& Ananthakrishnan, 1995), Parasarcophaga surcoufi (Ayaad et al., 2001), S. litura (Sharma et al., 2003) and Danaus chrysippus (Pandey et al., 2008). The decrease in the THC may be due to the formation of nodules comprised of groups of haemocytes or the inhibition of endocrine glands and their secretions (Tiwari et al., 2006). Azambuja \& Garcia (1992) record that when azadirachtin is administered via a blood meal to last nymphal instars of $R$. prolixus, the immune reactivity of this insect is reduced, as shown by a significant reduction in the THC and consequently nodule formation following challenge with Enterobacter cloacae $\beta$ 12, a reduction in the antibacterial activity of its haemolymph and consequent decrease in its ability to destroy an infection when inoculated with E. cloacae. Azadirachtin induces permanent resistance to infection with Trypanosoma cruzi in the vector of this protozoan parasite. On the other hand, Azambuja et al. (1991) failed to demonstrate that azadirachtin interfers with the PO-activating systems in the last nymphal instars of $R$. prolixus, since melanin production is not reduced when this system is stimulated by tyrosin or by the presence of bacteria in the haemolymph. Whereas, Ayaad et al. (2001) report that injection of azadirachtin into the haemocoele of the last larval instars of $P$. surcoufi significantly suppresses the PO activity of haemolymph even when the activators laminarin, $\alpha$-chymotrypsin and methanol are present. This suppression is dose-dependent and reaches a maximum at $30 \mathrm{~h}$ post-treatment. Injection of azadirachtin into the haemocoeloe of $P$. surcoufi larvae (Ayaad et al., 2001) and $S$. gregaria (Annadurai \& Rembold, 1993) induces the production of immune proteins.

Black spots develop on the head and thorax of Epilachna varivestis that have orally ingested azadirachtin (Schmutterer \& Rembold, 1980). These black regions consist of subcuticular deposits of melanin caused by the autolysis of parts of the epidermis, in particular those in the imaginal discs (Schlüter, 1981, 1985a, b). Similar melanotic changes can be induced within the larval fat body by injecting azadirachtin into the haemolymph, which may be due to azadirachtin interfering with premetamorphic events in the larvae (Schlüter, 1986; Schlüter \& Seifert, 1988).

\section{Juvenile hormone analogues}

There are relatively few studies on the effects of any of the hormones, for example, ecdysone, on haemocyte production. Vinson's (1993) review of the literature concludes that extirpation of the corpora allata or corpora cardiaca depresses haemocyte counts. The reverse is also true as is shown by implanting these organs. Similarly, implantation of a brain or injection of ecdysone also increases the THC in insects (Jones, 1967; Hoffmann, 1970; Nappi, 1974; Rao et al., 1984). Likewise, ElSheikh (1997) reports that pyriproxyfen significantly increases the THC and differential haemocyte count (oenocytoids) in T. granarium larvae. The number of prohaemocytes and spherulocytes is insignificantly increa- sed, whereas the number of plasmatocytes and granulocytes is insignificantly decreased.

It is well known that haemolymph volume and differentiation of haemocytes in insects are under hormonal control (Pathak, 1993a). The previous findings show that the increase in the hormonal titre in insects following implantation of corpora allata or corpora cardiaca or treatment with juvenile hormone analogues, increases the THC and the differentiation of the haemocytes. These findings indicate that antijuvenoids might be used to depress the THC and consequently the activity of an insect's immune system.

The development of melanotic nodules due to lamellocyte encapsulation in D. melanogaster can be increased by treating them with juvenile hormone-like substances (Bryant \& Sang, 1969; Madhaven, 1972). Earlier, Barigozzi $(1958,1969)$ thought these melanotic nodules are pseudotumors. However, this is not the case (Schlüter, 1981).

Lynn \& Vinson (1977) report that results of exposing Heliothis zea and $H$. virescens larvae to ecdysone or to hydroprene indicate that the encapsulation of the eggs of the parasitoid Cardiochiles nigriceps does not depend upon metamorphic hormones. Figueiredo et al. (2006) propose that ecdysone modulates phagocytosis in $R$. prolixus nymphs. Franssens et al. (2006) report that treatment of the $3^{\text {rd }}$ instar larvae of the flesh fly, Neobellieria bullata, with 20-hydroxyecdysone (20E) prior to injection with laminarin enhances the nodulation response in a dose-dependent manner. However, when the period between the treatment with $20 \mathrm{E}$ and injection of laminarin is less than $4 \mathrm{~h}, 20 \mathrm{E}$ did not influence the formation of nodules. Similarly, the non-steroidal ecdysone agonists, RH2484, RH5849 and RH0345 enhance the nodulation reaction, although they are less active than $20 \mathrm{E}$, since a higher dose and a longer period between treatments are required for these substances. In contrast to ecdysone stimulation, treating larvae with juvenile hormone or the juvenile hormone analogues, fenoxycarb and pyriporoxyfen, significantly impairs their ability to form nodules in response to laminarin. These findings demonstrate for the first time that $20 \mathrm{E}$ and juvenile hormone $(\mathrm{JH})$ play an important role in the nodulation process.

Oral administration of pyriproxyfen significantly suppresses the titer of lectins against both human $\left(\mathrm{O} \mathrm{Rh}^{+}\right)$ and rat erythrocytes in the last larval instars of $S$. littoralis just prior to pupation (El-Moataz Bellah \& Shaurub, 2000). These authors also point out that treatment of $S$. littoralis larvae with pyriproxyfen did not affect the properties of their lectins compared with those of control larvae, but new haemolymph proteins, which probably contained immune protein, are induced.

Injection of $120 \mathrm{p}$ moles of methoprene into the haemocoele of $4^{\text {th }}$ nymphal instars of $R$. prolixus significantly reduces the activity of haemolymph PO produced in response to a bacterial challenge (Nakamura et al., 2007). Similarly, the juvenoids, ZR-512, ZR-515, ZR-619 and ZR-777 enhance the activity of cuticle PO in Tribolium 
castaneum larvae fed on a diet containing 100 ppm of each compound (Ishaaya \& Yablonski, 1976).

Both JH and 20E have an antagonistic effect on the induction of antimicrobial peptide (AMP) genes in $D$. malanogaster (Flatt et al., 2008). Pretreatment of Schneider S2* cells, embryonic haemocytes or macrophage-like Drosophila cell line (Samakovlis et al., 1992), with 20E promotes a robust induction of AMP genes, following immune stimulation. On the other hand, JH III and its synthetic analogue (JHa), methoprene and pyriproxyfen, strongly interfer with 20E-dependent immune potentiation, but do not inhibit other 20Einduced cellular changes. Similarly in vivo analyses in adult flies confirm that $\mathrm{JH}$ is a hormonal immunosuppressant. RNA silencing of either partner of ecdysone receptor heterodimer (EcR or Usp) in S2* cells prevents 20E-induced immune potentiation. In contrast, silencing methoprene-tolerant (Met), a candidate $\mathrm{JH}$ receptor, did not impair immuno-suppression by JH III and JHa, indicating that in this context MET is not a necessary $\mathrm{JH}$ receptor. These authors suggest that $20 \mathrm{E}$ and $\mathrm{JH}$ are important in the regulation of gene expression in response to an immune challenge.

Hegazi et al. (2000) record that precocene II decreases the THC and numbers of granulocytes in S. littoralis larvae parasitized by the endoparasitoid Microplitis rufiventris. Further, Khafagi \& Hegazi (2001) found that both precocene I \& II cause a stronger encapsulation reaction in larvae of $S$. littoralis to the same parasitoid.

\section{Inert particles}

Several inert particles are phagocytosed or encapsulated when injected into several insect species. In some cases antimicrobial activity also increases following injection (Table 1).

The necrosis of phagocytic haemocytes of $G$. mellonella larvae following an overdose of iron saccharate accounts for the profound modifications in the haemo- gram recorded during the first $24 \mathrm{~h}$ post-treatment (Brehélin \& Hoffmann 1980). Complex factors have been isolated from the haemolymph of $G$. mellonella larvae following the injection of latex beads, which are readily encapsulated (Mohrig \& Schittek, 1979). These factors confer upon a naive larva the ability to clear its haemolymph from unphagocytizable Bacillus thuringiensis subtoxicus.

In insects, studies indicate a strong link between surface charge of abiotic material and encapsulation. In this context, negatively charged surfaces tend to be the least attractive (Lackie, 1983; Zahedi et al., 1992; Paskewitz \& Riehle, 1994). Similarly, parasites may take advantage of this lack of response to negatively charged surfaces (Hammerberg et al., 1984; Tackle \& Lackie, 1985; Christensen et al., 1986). This may be a consequence of the fact that the haemocoele of an insect is enclosed by the basal laminae of the insect organs, which are negatively charged, probably due to the presence of sulfated glycosaminoglycans (Locke, 1991; Paskewitz \& Riehle, 1994). This in turn would render the haemocytes unable to recognize abiotic agents as a foreign body and contributes to an electrostatic repulsive force between the cells and the negatively charged substrata (Zahedi et al., 1992; Paskewitz \& Riehle, 1994).

Research on processes linked to capsule formation has been predominantly on the prophenoloxidase (PPO) cascade. Thus other biochemical processes associated with encapsulation remain unknown. However, Cox-Foster \& Stehr (1994) have assayed FAD-glucose dehydrogenase (GLD) (FC 1.1.99.10) during the encapsulation of abiotic implants (sterile latex) in $4^{\text {th }}$ larval instars of $M$. sexta. No GLD activity was detected in fresh haemolymph or in haemocytes of both control and sham-treated larvae. By $24 \mathrm{~h}$ after implantation, GLD activity was detected in the encapsulation tissues in all larvae. The authors hypothesize that GLD participates in strengthening the encapsulation and killing reaction, via reaction with quinones

TABLE 1. Immunomodulations recorded in different species of insects injected with different inert particles.

\begin{tabular}{|c|c|c|c|}
\hline Abiotic agent & Immunomodulation & Insect species & Source \\
\hline Iron saccharate, latex & Phagocytosis & $\begin{array}{l}\text { L. migratoria, } \\
\text { G. mellonella }\end{array}$ & Brehélin \& Hoffmann (1980) \\
\hline $\begin{array}{l}\text { Carmine, polystyrene } \\
\text { beads, India ink, charcoal }\end{array}$ & Phagocytosis & S. littoralis & Pathak (1993a); Hassan et al. (1995). \\
\hline Araldite & Encapsulation & $\begin{array}{l}\text { Thermobia domestica, } \\
\text { Clitumnus extradentatus }\end{array}$ & $\begin{array}{l}\text { Grimstone et al. (1967); Francois (1975); } \\
\text { Schmidt \& Ratcliffe (1978) }\end{array}$ \\
\hline Cellophane, glass rods & Encapsulation & $\begin{array}{c}\text { L. migratoria, Melolontha } \\
\text { melolontha, Calliphora } \\
\text { erythrocephala }\end{array}$ & $\begin{array}{l}\text { Salt (1956); Matz (1965); Brehélin et al. } \\
\text { (1975); Zachary et al. (1975) }\end{array}$ \\
\hline Latex beads & Encapsulation & $\begin{array}{l}\text { G. mellonella, } \\
\text { Manduca sexta }\end{array}$ & $\begin{array}{l}\text { Lackie (1976); Mohrig \& Schittek (1979); } \\
\text { Wiesner (1991); Cox-Foster \& Stehr (1994) }\end{array}$ \\
\hline Nylon fibers & Encapsulation & $\begin{array}{l}\text { Bombyx mori, } \\
\text { Epirrita autumnalis }\end{array}$ & $\begin{array}{l}\text { Brewer \& Vinson (1971); Sato et al. (1976); } \\
\text { Plaistow (2001); Rantala \& Roff (2007) }\end{array}$ \\
\hline Silica beads & $\begin{array}{l}\text { Encapsulation, increase of anti- } \\
\text { bacterial \& lysozyme activities }\end{array}$ & G. mellonella & Wiesner \& Götz (1993) \\
\hline Polyester & Encapsulation & Euprepocnemis shiraki & Chang et al. (1991) \\
\hline Sephadex beads & Encapsulation & Armigeres subalbatus & Zahedi et al. (1992) \\
\hline
\end{tabular}


generated by PO and subsequent production of free radicals.

Borges et al. (2008) record a considerable change in the relative percentages of plasmatocytes, granulocytes, oenocytoids and prohaemocytes in the haemolymph of $5^{\text {th }}$ instar nymphs of the triatomine bug, $R$. prolixus, after challenge with latex beads. However, there was no significant change in the percentage of adipohaemocytes. They conclude that plasmatocytes are the only cells involved in phagocytosis. As in mammal cells, phagocytosis by both zipper and trigger mechanisms are observed for the uptake (after injection) of latex beads. Neither melanization nor microaggregation was observed.

A Plasmodium-refractory strain of Anopheles gambiae melanotically encapsulates many species of Plasmodium, whereas wild-type mosquitoes are usually susceptible. The melanization response to encapsulated Plasmodium and sephadex beads suggests that the mechanisms of bead and parasite melanization in the two mosquito strains share at least one major gene (Gorman et al., 1996, 1997).

\section{Antibiotics}

There is growing evidence that diverse classes of antibiotics have immunomodulatory effects, in addition to their antimicrobial activity (Pasquale \& Tan, 2005). While the immunomodulatory mechanisms of antibiotics are not fully understood, there is evidence that some directly reduce the activity of the host's immune system, whereas others limit the release of immunobacterial components (Tauber \& Nau, 2008).

Broderick et al. (2010) explored the potential role of the immune response of gypsy moth larvae, Lymnatria dispar, in mortality caused by $B$. thuringiensis in conjunction with gut bacteria. Two lines of evidence support such role. First, ingestion of B. thuringiensis by L. dispar led to a reduction in the number of haemocytes. Second, pharmacological agents that are known to modulate innate immune responses of invertebrates and vertebrates alter larval mortality induced by B. thuringiensis. Specifically, Gram-negative peptidoglycan pre-treated with lysozyme accelerated $B$. thuringiensis-induced killing of larvae previously made less susceptible by treating them with antibiotics. Conversely, several inhibitors of the immune response (eicosanoid inhibitors and antioxidants) increase a host's survival time following ingestion of $B$. thuringiensis. This may account for the decrease in insecticidal activity of $B$. thuringiensis against different insect species reported earlier by several authors using different antibiotics. For example, chlorotetracycline hydrochloride (Aureomycin) in sixth-instar Pseudaletia unipuncta larvae (Somerville et al., 1970) and 4-day-old larvae of Trichoplusia ni, H. virescens and Ostrinia nubilalis (Beegle et al., 1981), oxytetracycline hydrochloride (Terramycin) in D. melanogaster (Benz \& Graf, 1971) and dihydrostreptomycin in T. ni larvae (Ignoffo et al., 1977).

Cyclosporin A and beauverolide L are metabolites of cyclic peptides produced by several genera of entomopathogenic fungi, which are potent immunosuppressants (Vilcinskas et al., 1999). These authors demonstrate a strong immunomodulatory effect of beauverolide L and cyclosporin A in G. mellonella larvae. These two peptides enhance nodule formation and accompaning melanization in $G$. mellonella larvae injected with particles coated with sublethal concentrations ranging between 10 and $30 \mu \mathrm{g}$ per larva. In contrast, destruxins, another group of cyclic peptides released by, e.g. Metarhizium anisopliae, are reported to reduce both zymosan-induced nodule formation and activation of PO in Periplaneta americana and $S$. gregaria (Huxham et al., 1989). The injection of either dissolved or particle-bound destruxin in sublethal concentrations inhibits the induction of lysozyme and cecropinlike activity in the haemolymph of $G$. mellonella larvae (Vilcinskas et al., 1997b). In contrast, injection of either solubilized or particle-bound beauverolide L or cyclosporin A elicits a greater release of lysozyme and cecropin-like molecules than control injections of the solvent or non-coated particles (Vilcinskas et al., 1999). Fiolka (2008) found that cyclosporin A suppresses the humoral immune response of $G$. mellonella larvae immunized with LPS of $P$. aeruginosa and then injected with this antibiotic. The immunosuppressive effects are expressed both, in larvae treated with cyclosporin A at the initial phase of an immune response and at the phase of antibacterial activity. Cyclosporin A moderately decreases lysozyme activity and significantly decreases antibacterial peptides activity against Escherichia coli. Tricine SDS/PAGE indicates that synthesis of antibacterial phase of larvae treated with cyclosporin $\mathrm{A}$ is considerably inhibited. Insects with an immune response impaired by cyclosporin A lose their immunity to the bacterial pathogen $P$. aeruginosa.

Entomopathogenic fungi inhibit phagocytic activity, after treatment and spreading of plasmatocytes during pathogenesis in G. mellonella larvae (Vilcinskas et al., 1999). Earlier investigations reveal that the suppression of cellular immune responses during mycosis is probably mediated by fungal secondary metabolites (Vilcinskas et al., 1997a, b). Comparative analyses of the effects of fungal secondary metabolites on morphology and cytoskeleton formation by isolated plasmatocytes suggest that during infection with $M$. anisopliae it is predominantly the destruxins that affect host haemocytes (Vilcinskas et al., 1997b). The morphology and cytoskeleton alterations that occur when isolated plasmatocytes are incubated in vitro with cyclosporin A or beauverolide L differ from those of plasmatocytes from infected $G$. mellonella larvae or isolated plasmatocytes treated with destruxins or cytochalsins. These groups of fungal secondary metabolites are produced by $M$. anisopliae. They inhibit attachment, filopodia formation and stress fiber formation by plasmatocytes of G. mellonella (Vilcinskas et al., 1999).

Both actinomycin D and cycloheximide (inhibitors of eukaryotic protein synthesis) inhibit the expression of antibacterial immunity in Samia cynthia pupae, indicating that de novo synthesis of RNA and proteins occurred (Kaaya, 1993). Studies using actinomycin D show that 5 $\mathrm{h}$ are required for the synthesis of immune RNA (Boman et al., 1974; Faye et al., 1975; Boman \& Steiner, 1981). Actinomycin D and cycloheximide suppress the non-self 
response system in pupae of G. mellonella and Pieris rapae when they are applied at the induction phase of antibacterial immunity (Jarosz, 1994). Similarly, the antibacterial activity is drastically reduced in Pieris brassicae or completely depressed in most pupae of G. mellonella when actinomycin D or cycloheximide is administered shortly after immunization with E. cloacae (Jarosz, 1993). In the tsetse fly, Glossina morsitans, cycloheximide inhibits antibacterial activity, but increases the haemolymph lysozyme level (Kaaya et al., 1987; Kaaya, 1989). It seems likely; therefore, that cycloheximide lyses granular haemocytes, thus, releasing the lysozymes stored in these haemocytes (Zachary \& Hoffmann, 1984). Inhibition of immunity in $D$. melanogaster injected with cycloheximide is also recorded (Flyg et al., 1987).

Melanotic nodules are induced by chartreusin in the wing discs of the last larval instars of E. varivestis (Holst \& Schlüter, 1984).

\section{Heavy metals}

Industrialization causes an increase in the amount of trace elements in the environment. Heavy metals accumulate in insects and can exert toxic effects at all levels of biological organization (Hare, 1992). Nevertheless, there is little information on the immunity of insects exposed to environmental pollution. The phagocytic response and haemolymph PO activity of Mamestra brassicae larvae, fed on diets contaminated with copper, lead, cadmium or fluorine, to iron saccharate from yeast cells (heat-killed Saccharomyces cerevisiae) or viable Candida tropicalis have been recorded (Kazimírová \& Slovák, 1996). They found an increase in the percentage of plasmatocytes and a decrease in the percentage of granulocytes in copperstressed larvae and reduced phagocytosis of iron saccharate. Cadmium-and fluorine-treatment reduced phagocytosis in $S$. cerevisiae. Cadmium stimulates and copper inhibits phagocytosis in $C$. tropicalis. PO activity is reduced by all toxicants, reaching only $22 \%$ of that of the control in copper-stressed larvae. Borowska \& Pyza (2011) also record changes in haemocyte morphology and phagocytic plasticity in $M$. domestica larvae exposed to low or high, semi-lethal concentrations of copper, zinc, cadmium and lead. The number of plasmatocytes, regarded as stem cells, increases, while that of granulocytes responsible for phagocytosis decreases. However, there are no clear changes in the expression of the stress proteins (HSP70 or HSP72) in haemocytes treated with low or high concentrations of heavy metals.

Sorvari et al. (2007) studied the effect of industrial heavy metal contamination on the immune defence of a free-living wood ant (Formica aquilonia). They report higher levels of heavy metals in local colonies than in those translocated from none contaminated areas, but that the encapsulation response is similar in the two groups, indicating that the immune system of the local ants has not adapted to high levels of contamination. The encapsulation response is elevated by moderate but suppressed by high levels of heavy metals suggesting that there is a higher risk of infections in heavily polluted areas.
Larvae of the geometrid moth, Epirrita autumnata, that are fed on birch leaves coming from areas heavily polluted by heavy metals have an enhanced immune function (von Ooik et al., 2007). Further, von Ooik et al. (2008) found that a moderate amount of nickel and copper in the diet of this insect increases their encapsulation rate, but a large amount of copper adversely affects the immune system.

It is generally believed that industrial melanization in Lepidoptera is mainly caused by differential predation by insects. In polluted areas, melanic individuals are favored by natural selection because they are better camouflaged than pale moths on lichen-free and sooty trunks. Moreover, melanic individuals of Lymantria monarcha more quickly encapsulate monofilament nylon implants than pale moths (Mikkola \& Rantala, 2010). The same chemical precursors and their end product, melanin pigment, are involved in encapsulation and the melanic coloration.

\section{Radiation}

Tu et al. (2002) studied the effect of heavy ion beams $\left({ }^{12} \mathrm{C}^{5+}\right)$ on the silk worm, B. mori. They suggest that carbon-ion radiosurgery on haemopoietic organs of this insect induces not only a quantitative change, but also a qualitative change in the haemocytes at dose levels ranging from 50 to 300 Gy. Further, Ling et al. (2006) working also on ${ }^{12} \mathrm{C}^{5+}$ irradiated- $B$. mori, suggest that together with irradiation-escaped haemocytes the invaded circulating haemocytes took part in the regeneration of heavy ion beams-irradiated haemopoietic organs by the phagocytosis of injured haematocytes in vitro. ElMaasarawy \& El-Salam (1991) report that exposure of the same insect to $\gamma$-radiation $(0.15,5,10,30,50 \mathrm{~Gy})$ produces abnormalities of various types in haemolymph cells and the number of deformed cells increases with increase in the radiation dose. Tadashi (1982) found changes in the morphological form of Dacus cucurbitae after $\gamma$-irradiation. There are also ultrastructural changes in the larval haemocytes of $G$. mellonella irradiated as full grown pupae with $100,150,300,400$ Gy of $\gamma$-radiation (El-Kholy \& Abd El-Aziz, 2010). Similar changes in the total and differential haemocyte counts, due to irradiation, are also reported in other insect species. For example, in $\gamma$-irradiated Phthorimaea (= Gnorimoschema) operculella (El-Badry, 1964), P. americana (Eppensteiner \& Karp, 1989) and Helicoverpa armigera (Surisan et al., 2004) and X-irrdiated L. migratoria (Hoffmann, 1972; Grégoire, 1974). It is suggested that irradiation affects the constituent cells (Surisan et al., 2004) and the cell cycles in irradiated insects are delayed and the young stages are more affected than older stages (Tubiana et al., 1990).

Genchev et al. (2007) found that the capability of the haemolymph of $G$. mellonella to encapsulate sephadex beads (both in vivo and in vitro) is severely reduced after $\gamma$-irradiation. This is because the haemocytes are damaged by the irradiation. Whereas, exposing larvae of E. autumnata to ultraviolet-B (UV-B) radiation, mediated by UVB-exposed birch, did not significantly affect the rate at 
TABLE 2. Immunomodulation in insects following injection with miscellaneous abiotic agents.

\begin{tabular}{lccc}
\hline Abiotic agent & Immunomodulation & Insect species & Source \\
\hline Cane sugar factor* & Suppression of THC & B. mori & Ashida (1980) \\
& Increase in antibacterial \& lysozyme activities & G. mellonella & Pryce et al. (1990) \\
Physiological saline & Increase in antibacterial \& lysozyme activities & G. mellonella, P. brassicae & Jarosz (1988, (1993) \\
Haemolymph lysate & Increase in antibacterial \& lysozyme activities & G. mellonella & Wiesner (1993) \\
Sterile saline & Inhibition of the proteins $P_{1}, P_{4}, P_{5}, P_{7}, P_{8}$ & Hyalophora cecropia, S. cynthia & Faye et al. (1975) \\
Retinoids** & Reduction in haemolymph PO & R. prolixus & Nakamura et al. (2007) \\
Hydrocortisone & Depression in antibacterial activity & G. mellonella, P. rapae & Jarosz (1994) \\
\hline
\end{tabular}

* 72.2\% glucose, $2.6 \%$ amino acids, $25.2 \%$ unidentified substances; ** A class of chemical compounds that are related chemically to vitamin A.

which they encapsulated sterile nylon filaments (Anttila et al., 2010).

Nation et al. (1995) suggest that ionizing radiation inhibits the production of one or more enzymes involved in melanization, including PO. Inhibition of haemolymph PO following $\gamma$-irradiation is reported in Corcyra cephalonica (Raghvan et al., 1976), Ceratitis capitata (Mohamed \& Gerald, 1996), Ephestia küehniella and Tribolium confusum (Lupa \& Ignatowicz, 1999), $T$. granarium (Lupa, 2000), H. armigera (Surisan et al., 2004) and Callosobruchus chinensis (Supawan et al., 2005). Surisan et al. (2004) state that haemolymph PO in insects is localized in the haemocytes. The low enzyme level in irradiated insects is due to the ability of plasma to suppress PO activity in haemocytes, which implicates possible inhibitors in the irradiation. Moreover, irradiation decreases the size of the supraoesophageal ganglion (Rahman et al., 1990) and this might ultimately lead to a decrease in PO activity (Surisan et al., 2004).

\section{Miscellaneous substances}

Several authors report various forms of immunomodulation in insects following injection with miscellaneous abiotic agents (Table 2).

Melittin, the bee venom toxin, is active against the bacteria E. coli, Bacillus megaterium and Bacillus subtilis (Boman, 1982). The general design of melittin is similar to that of cecropins, but the polarity is reversed; thus in melittin the $\mathrm{C}$-terminal end is basic and the $\mathrm{N}$-terminal end is hydrophobic. Moreover, both proteins have a proline in the middle, a single tryptophan in front of a basic sequence stretch and amidated C-terminals formed from glycine residues (Boman \& Hultmark, 1987). Cecropin A lyses $E$. coli but not liver cells. However, melittin lyses both bacteria and liver cells (Steiner et al., 1981, Boman, 1982; Götz \& Boman, 1985). Cecropins appear to be specific for prokaryotic cells, whereas melittin acts on both prokaryotic and eukaryotic cells (Götz \& Boman, 1985; Boman \& Hultmark, 1987).

Abu El-Magd (1995) found that the oil of the black seed, Nigella sativa, added to the food of the last larval instars of $B$. mori does not activate in vitro haemolymph $\mathrm{PO}$ or play any role in the humoral deposition of capsule material. The essential oil of Acorus calamus decreases the THC and the number of prohaemocytes of $S$. litura 24-72 $\mathrm{h}$ after treatment (Sharma et al., 2008).
Orally administered luteolin (flavonoid) reduces the PO activity in $S$. exigua $3^{\text {rd }}$ instar larvae compared to nontreated larvae (Wang et al., 2010). Also, phenolics have a strong effect on the immune system of E. autumnata (Haviola et al., 2007; Ruuhola et al., 2007).

A sterilizing dose of the chemosterilant apholate reduces the haemolymph volume of both sexes in $D$. koenigii. The THC increases up to $48 \mathrm{~h}$, but then decreases in both sexes. The number of plasmatocytes in treated insects is reduced and the prohaemocytes became the predominant type, while in the control plasmatocytes are the dominant type (Bhargava \& Pilla, 1976).

When the silk worm, B. mori is fed on synthetic bombyxin-II (a peptide in the insulin family), the number of discharged haemocytes increases in a dose-dependent manner, indicating that bombyxin promotes cell proliferation in haematopoietic organs. Similarly, bovine albumin insulin increases haematopoietic activity. The haematopoietic activity of bombyxin and insulin is enhanced by the addition of 20E (Nakahara et al., 2006).

\section{CONCLUSION}

On the basis of current knowledge it can be concluded:

(i) Immunomodulation in insect pests treated with toxic abiotic agents should be taken into consideration before reaching a definite or comprehensive evaluation of their success as control agents. The effect of these chemicals on the functioning of insect immune systems depends on many factors, such as route of uptake, patterns of bioaccumulation, biotransformation, and excretion of immunotoxic compounds and the relationship of immunotoxic dose to other sublethal toxic effects.

(ii) The differentiation of haemocytes and possibly the total haemocyte count, which is influenced by the volume of haemolymph, may be influenced by certain hormones as extirpation of the corpora allata or corpora cardiaca depresses haemocyte transformation. In contrast, implantation of these organs, injection of ecdysone or treatment with juvenoids enhances the THC. Accordingly, negative changes in the THC and degree of differentiation of haemocytes might suppress the activity of an insect's immune system. This indicates that it might be advantageous to use antijuvenoids as probable immunosuppressants and also antimoulting compounds in integrated pest management strategies. 
(iii) If, as the literature suggests, melanotic encapsulation of abiotic agents (using beads as a model system) in both refractory strains of Anopheles results from the same physiological processes as parasite encapsulation, the bead assay could be a convenient tool for further investigations of refractoriness through genetic mapping and biochemical analysis leading to the identification of the gene involved in melanotic encapsulation. Because the melanization process must be activated or controlled in refractory and susceptible strains, identifying the genetic differences between these two strains may lead to the discovery of the factors involved in the melanization pathway. This may lead to studies on other insect-borne parasitic diseases other than malaria, such as trypanosomiasis, leishmaniasis and filariasis, aimed at identifying the factors responsible for success or failure of encapsulation in host-parasite associations. Genetic reciprocity is the basis for the adaptive strategies developed by these combatants in their co-evolutionary struggle. Knowledge of the interacting genetic mechanisms that govern host immunity and parasite resistance would contribute significantly to an understanding of the epidemiology of parasitic diseases. Moreover, such knowledge is fundamental in developing a comprehensive understanding of the physiological and biochemical aspects of these responses. Again, since these co-evolutionary adaptations operate at the population level, knowledge of the genetic components involved in host-parasite associations will significantly affect the development of biological control efforts and determine how these efforts can be effectively applied to natural populations.

ACKNOWLEDGEMENTS. I am grateful to A.A. Abdel-Samea, Assistant Lecturer, Department of Entomology, Faculty of Science, Cairo University, for his valuable assistance in preparing the revised manuscript.

\section{REFERENCES}

AbD El-Aziz N.M. \& Awad H.H. 2010: Changes in the haemocytes of Agrotis ipsilon larvae (Lepidoptera: Noctuidae) in relation to dimilin and Bacillus thuringiensis infections. Micron 41: 203-209.

Abu El-Magd A.A. 1995: Effect of the black seed Nigella sativa on the in vitro deposition of humoral capsule material by the haemolymph of Bombyx mori larvae. J. Egypt. Ger. Soc. Zool. (E) 16: 379-395.

Ambrose D.P. \& George P.J.E. 1996a: Effect of monocrotophos, dimethoate and methyl parathion on the differential and total haemocyte counts of Acanthaspis pedestris Stål (Insecta: Heteroptera: Reduviidae). Fresenius Envir. Bull. 5: 190-195.

Ambrose D.P. \& George P.J.E. 1996b: Effect of quinaphos and endosulfan on the differential and the total haemocyte counts of Acanthaspis pedestris Stål (Insecta: Heteroptera: Reduviidae). Fresenius Envir. Bull. 5: 207-212.

AnNADURAi R.S. \& Rembold H. 1993: Azadirachtin A modulates the tissue specific 2D polypeptide pattern of the desert locust, Schistocerca gregaria. Naturwissenschaften 80: 127-130.

Anttila U., Junlkumen-Titto R. \& Rousi M. 2010: Effects of elevated ultraviolet B-radiation on a plant-herbivore interaction. Oecologia 164: 163-175.
AshidA M. 1980: A cane sugar factor suppressing activation of prophenoloxidase in haemolymph of the silkworm, Bombyx mori. Insect Biochem. 11: 57-65.

Ayaad T.H., Dorrah M.A., Shaurub E.H. \& El-Saadawy H.A. 2001: Effects of the entomopathogenic nematode, Heterorhabditis bacteriophora HP88 and azadirachtin on the immune defense response and prophenoloxidase of Parasarcophaga surcoufi larvae (Diptera: Sarcophagidae). J. Egypt. Soc. Parasitol. 31: 295-325.

Azambuja P.D. \& Garcia E.S. 1992: Effects of azadirachtin on Rhodnius prolixus: immunity and Trypanosoma infection. Mem. Inst. Oswaldo Cruz Rio de Janeiro 87 (Suppl. 5): 69-72.

Azambuja P.D., Garcia E.S., Ratcliffe N.A. \& Warthen J.D. 1991: Immune-depression in Rhodnius prolixus induced by the growth inhibitor azadirachtin. J. Insect Physiol. 37: 771-777.

BARIgOzZI C. 1958: Melanotic tumors in Drosophila. J. Cell Comp. Physiol. 52: 371-381.

BARIGOZZI C. 1969: Genetic control of melanotic tumors in Drosophila. Nat. Cancer Inst. Monogr. 31: 277-290.

Beaulton J. \& MonPEyssin M. 1976: Ultrastructure and cytochemistry of the haemocytes of Antheraea pernyi Gyem. (Lepidoptera: Attacidae) during the $5^{\text {th }}$ larval stage. I - Prohaemocytes, plasmatocytes and granulocytes. J. Ultrastr. Res. 55: $143-156$.

Beegle C.C., Lewis L.C., Lynch R.E. \& Martinez A.J. 1981: Interaction of larval age and antibiotic on the susceptibility of three insect species to Bacillus thuringiensis. J. Invvertebr. Pathol. 37: 143-153.

Benz G. \& Graf E. 1971: Antagonism of terramycin on action of Bacillus thuringiensis "exotoxin" in Drosophila melanogaster. Experientia 27: 73-75.

Bhargava S. \& Pilla M.K.K. 1976: Haematological effects of apholate in the red cotton bug Dysdercus koenigii. Entomol. Exp. Appl. 20: 218-224.

Boman H.G. 1982: Humoral immunity in insects and the counter defense of some pathogens. Fortsch. Zool. 27: 211-222.

Boman H.G. \& Hultmark D. 1987: Cell-free immunity in insects. Annu. Rev. Microbiol. 41: 103-126.

Boman H.G. \& STEInER H. 1981: Humoral immunity in cecropia pupae. In Henle W. et al. (ed.): Current Topics in Microbiology and Immunology, 94/95. Springer, Berlin, Heidelberg, pp. 75-91.

Boman H.G., Faye I.N., Hofsten P.V., Kockum K., Lee J.Y., Xanthopoulos K.C., Bennich H., Engstrom A., Merrifield B.R. \& ANDRECh D. 1986: Antibacterial immune proteins in insects. A review of current prospectives. In Brehélin M. (ed.). Immunity in Invertebrates. Springer, Berlin, Heidelberg, pp. 63-73.

Boman H.G., Faye I.N. \& Rasmuson T. 1974: Why insect immunity? In Richter D. (ed.): Energy, Biosynthesis and Regulation in Molecular Biology. Walter de Gruyter, Berlin, pp. 103-114.

Borges A.R., Santos P.N., Furtado A.F. \& Figueiredo R.C.B.Q. 2008: Phagocytosis of latex beads and bacteria by haemocytes of the triatomine bug, Rhodnius prolixus (Hemiptera: Reduviidae). Micron 39: 486-494.

Borowska J. \& Pyza E. 2011: Effects of heavy metals on insect immunocompetent cells. J. Insect Physiol. 57: 760-770.

Brehélin M. \& Hoffmann J.A. 1980: Phagocytosis of inert particles in Locusta migratoria and Galleria mellonella: study of ultrastructure and clearance. J. Insect Physiol. 26: 103-111.

Brehélin M., Hoffmann J.A., Matz G. \& Porte A. 1975: Encapsulation of implanted foreign bodies by haemocytes of 
Locusta migratoria and Melolontha melolontha. Cell Tissue Res. 160: 283-289.

Brewer F.D. \& Vinson S.B. 1971: Chemical affecting the encapsulation of foreign material in an insect. J. Invertebr. Pathol. 18: 287-289.

Brey P.T. 1994: The impact of stress on insect immunity. Bull. Inst. Pasteur (Paris) 92: 101-118.

Broderick N.A., Raffa K.F. \& Handelsman J. 2010: Chemical modulators of the innate immune response alter gypsy moth larval susceptibility to Bacillus thuringiensis. BMC Microbiol. 10: 129.

Bryant P.J. \& SANG J.H. 1969: Physiological genetics of melanotic tumors in Drosophila melanogaster. VI. The tumorgenic effects of juvenile hormone-like substances. Genetics $\mathbf{6 2}$ : 321-336.

Bulet P. \& StÖCKLIN R. 2005: Insect antimicrobial peptides: structure, properties and gene regulation. Protein Pept. Lett. 12: 3-11.

Cerenius L. \& Söderhäll K. 2004: The prophenoloxidaseactivating system in invertebrates. Immunol. Rev. 198: 116-126.

Chang B.S., Yoe S.M., Kim W.K. \& Moon M.J. 1991: Electron microscope study on the haemocyte immune response to foreign substances in insects. II - Encapsulation. Kor. J. Entomol. 21: 119-131.

Christensen B.M., Forton K.F. \& Leonard M.M. 1986: Surface changes in Brugia phangi microfilariae and their association with immune evasion in Aedes aegypti. J. Invertebr. Pathol. 49: $14-18$.

Cox-Foster D.L. \& STEHR J.E. 1994: Induction and localization of FAD-glucose dehydrogenase (GLD) during encapsulation of abiotic implants in Manduca sexta larvae. J. Insect Physiol. 40: $235-249$.

Delpuech J., Frey F. \& Carton Y. 1996: Action of insecticides on the cellular immune reaction of Drosophila melanogaster against the parasitoid, Leptopilina boulardi. Envir. Toxicol. Chem. 15: 2267-2271.

Dietert R.P., Golemboski K.A., Kawak H., Ha R., Miller T.L. \& DAvison T.F. 1996: Environment-immune interactions. In Davison T.F., Morris T.R. \& Payne L.N. (eds): Poultry Immunology. Carfax, Abingdon, UK, pp. 343-356.

Dubovskiy I.M., Kryukov V., Benkovskaya G.V., YaroslavtSEVA V.V., Surina E.V. \& Glupov V.V. 2010: Activity of the detoxificative enzyme system and encapsulation rate in the Colorado potato beetle Leptinotarsa decemlineata (Say) larvae under organophosphorous insecticide treatment and entomopathogenic fungus Metarhizium anisopliae (Metsch.) infection. Euroasian Entomol. J. 9: 577-582.

EL-BADRY E. 1964: The effect of gamma irradiation on the haemocyte count of larvae of the potato tuber moth, Gnorimoschema operculella (Zeller). J. Insect Pathol. 6: 327-330.

El-Kholy E.M.S. \& ABD El-AzIz N.M. 2010: Effect of $\gamma$-irradiation on the biology and ultrastructure of haemocytes of greater wax moth, Galleria mellonella (L.) (Lepidoptera: Galleridae). Appl. Rad. Isotop. 68: 1671-1676.

El-Maasarawy S.A.S. \& El-Salam K.A.A. 1991: The effect of irradiation on the haemocyte picture in Bombyx mori L. larvae. Bull. Entomol. Soc. Egypt, Econ. Series 17: 63-76.

El-Moataz Bellah M.M. \& Shaurub E.H. 2000: Humoral immune response of the cotton leafworm, Spodoptera littoralis to the oral administration of pyriproxyfen and triflumuron. J. Egypt. Ger. Soc. Zool. (E) 31: 209-225.

EL-SHeIKH T.A.A. 1997: Combined Effects of Certain Insecticides and Insect Growth Regulators on Some Stored Grain Beetles. M. Sc. Thesis, Ain Shams University, Egypt.
EPPENSTEINER J.M. \& KARP R.D. 1989: The effect of gamma irradiation on the response to primary xenograft in the American cockroach, Periplaneta americana. J. Insect Physiol. 81: 81-86.

Faye I., Pye A., Rasmuson I., Boman H.G. \& Boman I.A. 1975: Insect immunity. II - Simultaneous induction of antibacterial activity and selective synthesis in diapausing pupae of Hyalophora cecropia and Samia cynthia. Infect. Immunol. 12: $1426-1438$.

Figueiredo M.B., Castro D.P., Nogueira N.F.S., Garcia E.S. \& Azambuja P. 2006: Cellular immune response in Rhodnius prolixus: role of ecdysone in haemocyte phagocytosis. $J$. Insect Physiol. 52: 711-716.

FiolKA M.J. 2008: Immunosuppressive effect of cyclosporin on insect humoral immune response. J. Invertebr. Pathol. 98: 287-292.

FISHER C.W. \& BRADY U.E. 1980: Increased rate of melanization in haemolymph of American cockroach (Periplaneta americana) and house cricket (Acheta domesticus) intoxicated by insecticides. Experientia 36: 93-94.

Flatt T., Heyland A., Rus F., Porpiglia E., Sherlock C., Yamamoto R., Garbuzov A., Palli S.R., Tatar M. \& SilVERMAN N. 2008: Hormonal regulation of the humoral innate immune response in Drosophila melanogaster. J. Exp. Biol. 211: 2712-2724

Flyg C., Dalhammar G., Rasmuson B. \& Boman H.G. 1987: Insect immunity: inducible antibacterial activity in Drosophila. Insect Biochem 17: 153-160.

FrançoIS J. 1975: L'encapsulation hémocytarie expérimentable chez le lépisme Thermobia domestica. J. Insect Physiol. 21: $1535-1546$.

Franssens V., Smagghe G., Simonet G., Claeys I., Breugelmans B., De Loof A. \& Brook J.V. 2006: 20-hydroxyecdysone and juvenile hormone regulate laminarin-induced nodulation in larvae of the flesh fly, Neobellieria bullata. Dev. Comp. Immunol. 30: 735-740.

Gad A.A. \& ABdel-Megeed A.C. 2006: Effects of spinosad and emamectin benzoate on the blood picture and DNA structure of the cotton leafworm Spodoptera littoralis (Boisd.) (Lepidoptera: Noctuidae). Egypt. Sci. Mag. 3: 102-118.

Genchev N.P., Milcheva-Dimitrova R.Y. \& Kozhuharova M.V. 2007: Use of gamma radiation for suppression of the haemocytic immune response in larvae of Galleria mellonella (Lepidoptera) against Venturia canescens (Hymenoptera). $J$. Balk. Ecol. 10: 411-419.

George P.J.E. \& Ambrose D.P. 1998: Total and differential haemocytes in the life stages and adult haemocyte morphology in Acanthaspis pedestris Stål. Ind. J. Entomol. 60: 228-232.

George P.J.E. \& Ambrose D.P. 2000: Impact of insecticide on the differential and the total haemocyte counts of Rhynocoris marginatus (Fabricius) (Insecta: Heteroptera: Reduviidae). Ind. J. Sci. 4: 169-173.

Gillespie L.P., Kanost M.R. \& Trenczek T. 1997: Biological mediators of insect immunity. Annu. Rev. Entomol. 42: 611-643.

Gorman M.J., Cornel A.J., Collins F.H. \& Paskewitz S.M. 1996: A shared genetic mechanism for melanotic encapsulation of CM-sephadex beads and a malaria parasite, Plasmodium cynomolgi B, in the mosquito, Anopheles gambiae. Exp. Parasitol. 84: 380-386.

Gorman M.J., Saverson D.W., Cornel A.J., Collins F.H. \& PAsKewitz S.M. 1997: Mapping a quantitative trait locus involved in melanotic encapsulation of foreign bodies in the malaria vector, Anopheles gambiae. Genetics 146: 965-971. 
GöтZ P. 1986: Encapsulation in arthropods. In Brehélin M. (ed.): Immunity in Invertebrates. Springer, Berlin, Heidelberg, pp. $153-170$.

Götz P. \& Boman H.G. 1985: Insect immunity. In Kerkut G.P. \& Gilbert L.I. (eds): Comprehensive Immunology, Biochemistry and Physiology. Pergamon Press, Oxford, New York, pp. 453-485.

GrÉGOIRE C. 1974: Haemolymph coagulation. In Rockstein M. (ed.): The Physiology of Insecta. Vol. 5. 2nd ed. Academic Press, New York, pp. 309-360.

Grimstone A.V., Rotheram S. \& Salt G. 1967: An electronmicroscope study of capsule formation by insect blood cells. J. Cell Sci. 2: 201-292.

GuPTA A.P. 1985: Cellular elements in the haemolymph. In Kerkut G.A. \& Gilbert L.I. (eds): Comprehensive Insect Physiology, Biochemistry and Pharmacology. Pergamon Press, Oxford, New York, pp. 401-451.

GuPTA A.P. \& SutherLAND D.J. 1966: In vitro transformation of the insect plasmatocyte in some insects. J. Insect Physiol. 12: 1369-1375.

Halawa S., Gaaboub I., Gad A.A. \& El-Aswad A.E. 2007: Effect of some insecticides on the haemolymph of the desert locust Schistocerca gregaria Forskal. J. Egypt. Soc. Toxicol. 36: 61-66.

HAMmerberg B., Rikinisa Y. \& King M.W. 1984: Immunoglobulin interactions with surfaces of sheathed and unsheathed microfilariae. Parasite Immunol. 6: 421-434.

HAQ M.R., SABRi M.A. \& RAShid A. 2005: Toxicity of nicotinyl insecticides on the haemocytes of red cotton bug, Dysdercus koenigii (Fb.) (Pyrrhocoridae). J. Agr. Soc. Sci. 1: 239-241.

HARE L. 1992: Aquatic insects and metals: bioavailability, bioaccumulation and toxicity. Crit. Rev. Toxicol. 22: 327-369.

Hassan T., El-Deeb S., SaAd A. \& El-Moursy A. 1995: Phagocytic activity of haemocytes for the Egyptian cotton leafworm, Spodoptera littoralis (Boisd). J. Egypt. Ger. Soc. Zool. (E) 18: 37-57.

Haviola S., Kapari L., Ossipov V., Rantala M.J., Ruhhola T. \& HaukioJa E. 2007: Foliar phenolics are differently associated with Epirrita autumnata growth and immunocompetence. J. Chem. Ecol. 33: 1013-1023.

Hegazi E.M., El-Shazli A.Y., Hafez M.B. \& Abd El-Aziz G.M. 2000: Influence of precocene II on the estimated changes with the haemocyte population of parasitized Spodoptera littoralis larvae by Microplitis rufiventris. Arch. Phytopathol. Plant Protec. 33: 351-360.

Hegazi E.M., Khafagi W.E. \& El-Aziz G.M.A. 1998: Effect of lefenuron, a chitin synthesis inhibitor, on encapsulation response of Spodoptera littoralis larvae to surplus Microplitis rufiventris larvae. Insect Sci. Appl. 18: 357-363.

HofFmanN J.A. 1970: Endocrine regulation of the production and differentiation of haemocytes in an orthopteran insect, Locusta migratoria. Gen. Comp. Endocrinol. 15: 198-219.

HofFMANN J.A. 1972: Modification of the haemogram of larval and adult Locusta migratoria after selective X-irradiation of the haemocytopoietic tissues. J. Insect Physiol. 18: $1639-1652$

Hoffman J.A., Kafatos F.C., Janeway C.A. \& Ezekowitz R.A. 1999: Phylogenetic perspectives in innate immunity. Science 284: $1313-1318$.

Holst H. \& SCHLÜTER U. 1984: Effects of the antibiotic chartreusin on Epilachna varivestis Muls. (Coleoptera, Coccinellidae). In: Abstract Volume. XVII Inter. Cong. Entomol., Hamburg, Aug. 20-26, 1984. R 16.2.4.

HuXHam I.M., LaCKIE A.M. \& McCorcindale N.J. 1989: Inhibitory effects of cyclodepsipeptides, destruxines, from the fungus Metarhizium anisopliae, on cellular immunity in insects. J. Insect Physiol. 35: 97-105.

Ignoffo C.M., Garcia C. \& Couch T.L. 1977: Effect of antibiotics on the insecticidal activity of Bacillus thuringiensis. $J$. Invertebr. Pathol. 30: 277-278.

IshaAYA I. \& CASIDA J.E. 1974: Dietary TH 6040 alters composition and enzyme activity of housefly larval cuticle. Pestic. Biochem. Physiol. 4: 484-490.

ISHAAYA I. \& YABLONSKI S. 1976: Induction of prolonged larval feeding stage by juvenile hormone analogus in Tribolium castaneum. Phytoparasitology 4: 9-18.

JAROSZ J. 1988: The use of saline W, a physiological salt solution for experimentation on insect immunity. Cytobiology 53: $19-29$.

JAROSZ J. 1993: Induction kinetics of immune antibacterial proteins in pupae of Galleria mellonella and Pieris brassicae. Comp. Biochem. Physiol. (B) 106: 415-421.

JAROSZ J. 1994: Modulation of cell-free immune response in insects. Cytobiology 79: 169-180.

JAROSZ J. \& GLINSKI Z. 1999: Relationship of pesticides to insect cell-free immune response. Ann. Univ. Mariae Curie Sklodowska (Sec. DD, Med. \& Vet.) 54: 195-201.

JiRAVANIChPaisal P., LeE B.L. \& SöDERhäLL K. 2006: Cellmediated immunity in arthropods: haematopoiesis, coagulation and opsonization. Immunobiology 211: 213-236.

JoNES J.C. 1962: Current concepts concerning insect haemocytes. Am. Zool. 2: 209-246.

JONES J.C. 1967: Effect of repeated haemolymph withdrawals and of ligaturing the head on differential haemocyte counts of Rhodnius prolixus. J. Insect Physiol. 13: 1351-1360.

KaAYA G.P. 1989: Assessment of antibiotic potentials of insect antibacterial factors. Insect Sci. Appl. 10: 341-346.

KAAYA G.P. 1993: Inducible, humoral antibacterial immunity in insects. In Pathak J.P.N. (ed.): Insect Immunity. Oxford \& IBH Publishing, New Delhi, Bombay, Calcutta, pp. 69-89.

KaAya G.P., Flyg C. \& Boman H.G. 1987: Insect immunity: Induction of cecropin and attacin-like antibacterial factors in the haemolymph of Glossina morsitans morsitans. Insect Biochem. 17: 309-315.

Kazimírova M. \& SLovÁK M. 1996: Effects of heavy metals and fluorine on phagocytosis and phenoloxidase activity in Mamestra brassicae (Lepidoptera: Noctuidae). Eur. J. Entomol. 93: 467-473.

Khafagi W.E. \& Hegazi E.M. 2001: Effect of juvenile hormones and precocenes on the immune response of Spodoptera littoralis larvae to supernumerary larvae of the solitary parasitoid Microplitis rufiventris Kok. J. Insect Physiol. 47: 1249-1259.

Kurihara Y., Shimazu T. \& Wago S. 1992: Classification of haemocytes in the common cutworm Spodoptera litura (Lepidoptera: Noctuidae). I - Phase microscopic study. Appl. Entomol. Zool. 27: 225-235.

LACKIE A.M. 1976: Evasion of the haemocytic defense reaction of insects by larvae of Hymenolepis diminuta (Cestoda). Parasitol. 75: 91-104.

LACKIE A.M. 1983: Effect of substratum wettability and charge on adhesion in vitro and encapsulation in vivo by insect haemocytes. J. Cell Sci. 63: 181-190.

Landa V., Šula J., Marec F., MaťHa V. \& Soldán T. 1991: Methods for assessing exposure of insects. In Tardiff R.G. \& Goldstein B. (eds): Methods for Assessing Exposure and NonHuman Biota. John Willey \& Sons, New York, pp. 249-266.

LEE R.M. 1961: The variation of blood volume with age in the desert locust (Schistocerca gregaria Forskal). J. Insect Physiol. 6: 36-51. 
Lim S.J. \& LeE S.S. 1982: The toxicity of diflubenzuron on Oxya japonica (Willemse) and its effects on moulting. Pestic. Sci. 13: 537-544.

Ling E., Shirai K., Kanekatsu R., Kiguchi K., Kobyashi Y., Funayama T. \& Watanabe H. 2006: Contribution of circulating haemocytes to the regeneration of heavy ion beams $\left({ }^{12} \mathrm{C}^{5+}\right)$ irradiated haematopoietic organs in the silk worm Bombyx mori, through the way of phagocytosis of injured cells after invasion. Dev. Comp. Immunol. 30: 531-543.

Liu S., Niu H., Xiao T., Xue C., Liu Z. \& Luo W. 2009: Does phenoloxidase contributed to the resistance? Selection with butane-fibronil enhanced its activity from diamondback moth. Open Biochem. J. 3: 9-13.

Liu S., Niu H., Xiao T., Xue C., Liu Z. \& Luo W. 2010: Characteristics of immune function and the response against the insecticides and other external interference factors on insect phenoloxidase. http://www.china-papers.com/?p=63468.

LOCKE M. 1991: Insect epidermal cells. In Binnington K. \& Retnakara A. (eds): Physiology of the Insect Epidermis. CSIRO Publications, East Melbourne, pp. 1-20.

LuPA D.A. 2000: Reduced activity of phenoloxidase after treatment with gamma radiation in larvae of the khapra beetle, Trogoderma granarium (Evertis), as an easy method to detect irradiated and non-irradiated insects. Ann. Warsan Univ. Agric. Hortic. (Lansc. Archit.) 21: 9-16.

Lupa D.A. \& Ignatowicz S. 1999: Changes of phenoloxidase activity in stored product pests treated with ionizing radiation. Prog. Plant Prot. 39: 458-462.

Luster M.I., Germolec D.R., Kayama F., Rosenthal G.I., ComMENT C.E. \& WiLMEN J.C. 1996: Approaches and concepts in immunotoxicology. In Smialowicz R.J. \& Holsappe M.P. (eds): Experimental Immunotoxicology. CRC Press, Boca raton, FL, pp. 13-27.

Luster M.I. \& Rosenthal G.J. 1993: Chemical agents and the immune response. Envir. Perspect. 100: 219-236.

LYNN D.C. \& VINSON S.B. 1977: Effects of temperature, host age and hormones upon the encapsulation of Cardiochilis nigriceps eggs by Heliothis sp. J. Invertebr. Pathol. 29: 50-55.

MADHAVEN K. 1972: Induction of melanotic pseudotumors in Drosophila melanogaster by juvenile hormone. Wilhelm Roux's Arch. Dev. Biol. 169: 345-349.

Mahmood A. \& Yousof M. 1985: Effect of some insecticides on the haemocytes of Gryllus bimaculatus de Geer. Pak. J. Zool. 17: 71-84.

Mall S.B. \& GuPTA G.S. 1982: Haemocyte picture during metamorphosis of Atteva fabriciella (Swed.). Ind. J. Entomol. 44: $101-112$.

Matz G. 1965: Implantation de fragments de cellophané chez Locusta migratoria L. Bull. Soc. Zool. Fr. 90: 429-433.

Mikkola K. \& Rantala M.J. 2010: Immune defense, a possible nonvisual selective factor behind the industrial melanism of moths (Lepidoptera). Biol. J. 99: 831-838.

Mohamed M. \& Gerald F. 1996: Effect of gamma radiation on phenoloxidase activity in Mediterranean fruitfly (Diptera: Tephritidae) larvae. J. Econ. Entomol. 89: 695-699.

Mohammed T.R.A. 1998: Biochemical and Physiological Studies of Some Insect Growth Regulators on the Cotton Leafworm, Spodoptera littoralus (Boisd.). Ph.D. Thesis, Cairo University.

Mohrig W. \& Schittek D. 1979: Phagocytosis-stimulating mediators in insects. Acta. Med. Ger. 38: 953-958.

Nakahara Y., Matsumoto H., Kanamori Y., Kataoka H., Mizoguchi A., Kiuchi M. \& Kamimura M. 2006: Insulin signaling is involved in haematopoietic regeneration in an insect haematopoietic organ. J. Insect Physiol. 52: 105-111.
Nakamura A., Stilbler R., Fantappie M.R., Fialho E., Masuda H. \& Oliveira M.F. 2007: Effects of retinoids and juvenoids on moult and on phenoloxidase activity in the blood-sucking insect Rhodnius prolixus. Acta Trop. 103: 222-230.

NAPPI A.J. 1974: Insect haemocytes and the problem of host recognition. In Cooper E.L. (ed.): Contemporary Topics in Immunology. Vol. IV. Plenum Press, New York, London, pp. 201-224.

NAPPI A.J. \& Sugumaran M. 1993: Some biochemical aspects of eumelanin formation in insect immunity. In Pathak J.P.N. (ed.): Insect Immunity. Oxford \& IBH Publishing, New Delhi, Bombay, Calcutta, pp. 131-148.

Nation J., Smith B.J. \& Milne K. 1995: Radiation-induced changes in melanization and phenoloxidase in Caribbean fruitfly larvae (Diptera: Tephritidae) as the basis for a simple test of irradiation. Ann. Entomol. Soc. Am. 88: 201-205.

Pandey J.P., Tiwari P.K. \& Kumar D. 2008: Reduction in haemocyte mediated immune response in Danaus chrysippus following treatment with neem based insecticides. J. Entomol. 5: 200-206.

Paskewitz S. \& Riehle M. 1994: Response of Plasmodium refractory and susceptible strains of Anopheles gambiae to inoculated sephadex beads. Dev. Comp. Immunol. 18: 369-375.

PASQUale T.R. \& TAN J.S. 2005: Non-antimicrobial effect of antimicrobial agents. Clin. Infect. Dis. 40: 127-135.

PАтнак J.P.N. 1983: Effects of endocrine glands on the unfixed total haemocyte counts of the bug Halys dentata. J. Insect Physiol. 29: 91-94.

PATHAK J.P.N. 1991: Effect of endocrine extracts on the blood volume and population of haemocytes in Halys dentata (Pentatomidae, Heteroptera). Entomon 16: 251-255.

PAthaK J.P.N. 1993a: Cell-mediated defense reactions in insects. In Pathak J.P.N. (ed.): Insect Immunity. Oxford \& IBH Publishing, New Delhi, Bombay, Calcutta, pp. 47-58.

Pатнак J.P.N. 1993b: Haemagglutinis (lectins) in insects. In Pathak J.P.N. (ed.): Insect Immunity. Oxford \& IBH Publishing, New Delhi, Bombay, Calcutta, pp. 149-169.

Pathak S.C. \& Kulshreshtha V. 1993: Variation in haemocyte types with reference to reproduction activity in Blatella germanica L. (Dictyoptera: Blattidae) and the occurrence of undescribed haemocyte types in some adult stages. Entomon 18: 119-125.

Patton R.L. 1961: The detoxification function of insect haemocytes. Ann. Entomol. Soc. Am. 52: 240-242.

Peter A.J. \& Ananthakrishnan T.M. 1995: Impact of azadirachtin on the haemolymph of Cyrtacanthacris tatarica L. (Acridiidae: Orthoptera). J. Entomol. Res. 19: 285-290.

Pilat M. 1935: The effect of intestinal poisoning on the blood of locusts (Locusta migratoria). Bull. Entomol. Res. 26: 283-292.

Plaistow J. 2001: Investment in immune function under chronic and acute immune challenge in an insect. Physiol. Entomol. 23: $1-5$.

Prakash B., Bhargava S. \& Rawat K. 2007: Effect of penfluron on total haemocyte count of Dysdercus koenigii. Asian J. Exp. Sci. 21: 151-154.

Pryce M.J., Astone W.P. \& Chadwick J.S. 1990: Cane sugar factor as an inducing agent of immunity in Galleria mellonella. Dev. Comp. Immunol. 14: 369-378.

Pugazhvendan S.R. \& Soundararajan M. 2009: Effect of penfluron on total haemocyte count of Chrysocoris purpureus. Middle-East J. Sci. Res. 4: 338-340.

RaghVan K.G., Ramakrishnan V. \& Nadkarni G.B. 1976: Tyrosine metabolism in gamma-irradiated rice moth, Corcyra cephalonica. Rad. Res. 67: 46-55. 
Rahman R.C., Rigney C. \& Bush-Petersen E. 1990: Irradiation as a quarantine treatment against Ceratitis capitata (Diptera: Tephritidae): anatomical and cytogenetic changes in mature larvae after gamma irradiation. J. Econ. Entomol. 83: $1449-1454$.

Rantala M.J. \& Roff D.A. 2007: Inbreeding and extreme outbreeding cause sex difference in immune defense and life history traits in Epirrita autumnata. Heredity 98: 329-336.

Rao C.C.P., Ray A. \& Ramamurthy P.S. 1984: Effect of ligation and ecdysone on total haemocyte count in the tobacco caterpillar, Spodoptera littoralis (Noctuidae, Lepidoptera). Can. J. Zool. 62: 1461-1463.

RATClifFe N.A. \& Rowley A.F. 1979: Role of haemocytes in defense against biological agents. In Gupta A.P. (ed.): Development, Forms, Functions \& Techniques. Cambridge University, Cambridge, pp. 331-414.

Ruuhola T., Salminen J.P., Haviola S., Yang S.Y. \& Rantala M.J. 2007: Immunological memory of mountain birches: the effect of phenolics on the performance of the autumnal moth depend on the herbivory history of trees. J. Chem. Ecol. $\mathbf{3 3}$ 1160-1176.

SAFE S.H.C. 1994: Polychlorinated biphenyls (PCBs): environmental impact, biochemical and toxic responses and implications for risk assessment. Crit. Rev. Toxicol. 24: 87-149.

SALT G. 1956: Experimental studies in insect parasitism. IX The reactions of a stock to an alien parasite. Proc. R. Soc. Lond. (B) 149: 93-108.

Samakovlis C., Asling B., Boman H.G., GatefF E. \& Hultmark D. 1992: In vitro induction of cecropin genes - an immune response in a Drosophila blood cell line. Biochem. Biophys. Res. Commun. 188: 1169-1175.

Sato S., Akai H. \& Sawada H. 1976: An ultrastructural study of capsule formation by Bombyx mori. Zool. Jap. 49: 177-188.

SAXENA B.P. \& TikKu K. 1990: Effect of plumbagin on haemocytes of Dysdercus koenigii F. Proc. Ind. Acad. Sci. (Anim. Sci.) 99: 119-124.

SCHLÜTER U. 1981: Histological observations on the phenomenon of black legs and thoracic spots: effects of pure fractions of neem kernel extracts on Epilachna varivestis. In Schmutterer H., Ascher K.R.S. \& Rembold H. (eds): Natural Pesticides from the Neem Tree (Azadirachta indica A. Juss.). GTZ, Eschborn, pp. 97-104.

SCHLÜTER U. 1985a: Die Wirkung von Azadirachtin auf Gewebe von Insekten: Epidermis und Imaginal-anlagen von Epilachna varivestis Muls. (Coleoptera, Coccinillidae). Mitt. Dt. Ges. Allgem. Angew. 4: 197-200.

SCHLÜTER U. 1985b: Disturbance of epidermal and fat body tissue after feeding azadirachtin and its consequence on larval moulting in the Mexican bean beetle, Epilachna varivestis (Coleoptera, Coccinillidae). Entomol. Genet. 10: 97-110.

SCHLÜTER U. 1986: Knötchenbildung in Fettkörper des Bohnenköfers Epilachna varivestis. Verh. Dt. Zool. Ges. 79: 392.

SCHLÜTER U. \& SEIFERT G. 1988: Inducing melanotic nodules within fat body of the last instar larvae of Epilachna varivestis (Coleoptera, Coccinillidae) by azadirachtin. J. Invertebr. Pathol. 51: 1-9.

Schmidt A.R. \& Ratcliffe N.A. 1978: The encapsulation of araldite implants: Recognition of foreigness in Clitumnus extradentatus. J. Insect Physiol. 24: 511-521.

Schmutterer H. \& Rembold H. 1980: Zur Wirkung einiger Reinfraktionen aus Samen von Azadirachta indica auf Frassaktivität und Metamorphose von Epilachna varivestis (Coleoptera, Coccinillidae). Z. Angew. Entomol. 89: 179-188.

Sharma P.R., Sharma O.P. \& SaXena B.P. 2003: Effect of neem gold on haemocytes of the tobacco armyworm. Curr. Sci. 84: 690-695.
Sharma P.R., Sharma O.P. \& Saxena B.P. 2008: Effect of sweet flag rhizome oil (Acorus calamus) on haemogram and ultrastructure of haemocytes of the tobacco armyworm, Spodoptera litura (Lepidoptera: Noctuidae). Micron 39: 544-551.

SöDERHÄLl K. \& AsPÁN A. 1993: Prophenoloxidase activating system and its role in cellular communication. In Pathak J.P.N. (ed.): Insect Immunity. Oxford \& IBH Publishing, New Delhi, Bombay, Calcutta, pp. 113-129.

Somerville H.J., TANAdA Y. \& OMI E.M. 1970: Lethal effect of purified spore and crystalline endotoxin preparations of Bacillus thuringiensis on several lepidopterous insects. $J$. Invvertebr. Pathol. 16: 241-248.

Sorvari J., Rantala L.M., Rantala M.J., Hakkarainen H. \& Eeva T. 2007: Heavy metal pollution disturbs immune response in wild ant populations. Envir. Pollut. 145: 324-328.

Steiner H., Hultmark D., Engstrom H. \& Boman H.G. 1981: Sequence and specificity of two antibacterial proteins involved in insect immunity. Nature 292: 246-248.

Supawan J., Hormchan P., Sutantawong M. \& Wongpiyasatid A. 2005: Effects of gamma radiation on Azuki bean weevil, Callosobruchus chinensis (L.). Kasetsart J. (Nat. Sci.) 39: 206-215.

Surisan S., Horchman P., Jamornmarn S., Wongpiyasatid A. \& Engkakuta A. 2004: Potential methods for identification the gamma irradiation from unirradiated larvae of Helicoverpa armigera Hübner (Lepidoptera, Noctuidae). Kasetsart J. (Nat. Sci.) 38: 57-64

TACKLE G.B. \& LACKIE A.M. 1985: Chemokinetic bahaviour of insect haemocytes in vitro. J. Cell Sci. 85: 85-94.

TADASHI T. 1982: Sterilization of the melon fly, Dacus cucurbitae Coq. (Diptera: Tephritidae), with gamma-radiation: recovery of fertility of flies irradiated as mature pupae. Appl. Entomol. Zool. 17: 586-589.

TAUBer S.C. \& NAU R. 2008: Immunomodulatory properties of antibiotics. Curr. Mol. Pharmacol. 1: 68-79.

Tiwari R.K., Pandey J.P. \& Kumar D. 2006: Effect of neem based insecticides on metamorphosis, haemocyte count and reproductive behaviour in red cotton bug, Dysdercus koenigii (Heteroptera: Pyrrhocoridae). Entomon 31: 267-275.

Tsakas S. \& Marmaras V.J. 2010: Insect immunity and its signaling: An overview. Invertebr. Surv. J. 7: 228-238.

Tu Z., Kobayashi Y., Kiguchi K., Watanabae H. \& Yamamato K. 2002: Effect of heavy-ion radiosurgery on the haemopoietic function of the silkworm, Bombyx mori. J. Rad. Res. 43: 269-275.

Tubiana M.J., Dutreix J. \& Wambersie A. 1990: Introduction to Radiation Biology. Taylor \& Fracis, London, New York, 371 pp.

UCKAN F. \& SAK O. 2010: Cytotoxic effect of cypermethrin on Pimpla turionellae (Hymenoptera: Ichneumonidae) larval haemocytes. Ekoloji 19: 20-26.

Vilcinskas A., Jegorov A., Landa Z., Götz P. \& Matha V. 1999: Effects of beauverolide L and cyclosporin A on humoral and cellular immune response of the greater wax moth, Galleria mellonella. Comp. Biochem. Physiol. (C) 122: 83-92.

Vilcinskas A., Matha V. \& Götz P. 1997a: Inhibition of phagocytic activity of plasmatocytes isolated from Galleria mellonella by entomogenous fungi and their secondary metabolites. J. Insect Physiol. 43: 475-483.

Vilcinskas A., Matha V. \& Götz P. 1997b: Effects of the entomopathogenic fungus Metarhizium anisopliae and its secondary metabolites on morphology and cytoskeleton of plasmatocytes isolated from the greater wax moth, Galleria mellonella. J. Insect Physiol. 43: 1149-1159. 
Vilmos P. \& KuRUCZ E. 1998: Insect immunity: evolutionary roots of the mammalian innate system. Immunol. Lett. 62: $59-66$.

VINSON S.B. 1990: Immunosuppression. In Baker R.R., Dunn P.E. (eds): New Direction in Biological Control: Alternatives for Suppressing Agricultural Pests and Diseases. Alan R. Liss, New York, pp. 517-535.

VINSON S.B. 1993: Interactions between the insect endocrine system and the immune system. In Pathak J.P.N. (ed.): Insect Immunity. Oxford \& IBH Publishing, New Delhi, Bombay, Calcutta, pp. 103-112.

von Ooik T., Pausio S. \& Rantala M.J. 2008: Direct effects of heavy metal pollution on the immune function of geometrid moth, Epirrita autumnata. Chemosphere 71: 1840-1844.

von OoIK T., Rantala M.J. \& SAlORRIENI I. 2007: Diet-mediated effects of heavy metal pollution on geometrid moth, Epirrita autumnata. Envir. Pollut. 145: 348-354.

WAGO H. 1980: Observation of the early process of phagocytosis by the granular cells of the silkworm Bombyx mori. Appl. Entomol. Zool. 15: 489-491.

WaGO H. 1983: The important significance of filopodial function of phagocytic granular cells of the silkworm, Bombyx mori in recognition of foreigness. Dev. Comp. Immunol. 7: 445-453.

Wang S., Liu W., XuE C. \& Luo W. 2010: The effect of luteolin on phenoloxidase and the growth of Spodoptera exigua (Hübner) larvae (Lepidoptera: Noctuidae). J. Pestic. Sci 35: 483-487.

WheELER R.G. 1963: Studies on total haemocyte count and haemolymph volume in Periplaneta americana (L.) with reference to the last moulting cycle. J. Insect Physiol. 9: 223-235.

WIESNER A. 1991: Induction of immunity by latex beads and by haemolymph transfer in Galleria mellonella. Dev. Comp. Immunol. 15: 241-250.
WIESNER A. 1993: Further observations on the induction of immunity by haemolymph transfer in Galleria mellonella. Dev. Comp. Immunol. 17: 291-300.

WIESNER A. \& GötZ P. 1993: Silica beads induce cellular and humoral immune responses in Galleria mellonella larva and isolated plasmatocytes, obtained by a newly adapted nylon wool separation method. J. Insect Physiol. 39: 856-876.

Xue C., Luo W., Chen Q., Ma D. \& Wang Q. 2008: Inhibitory effects of 2-hydroxybenzaldehyde on the activity of phenoloxidase from Pieris rapae (Lepidoptera) larvae. Ind. J. Biochem. Biophys. 45: 184-191.

YAN J.Y., JIE Y., CUI Q.X. \& HuI L. 2010: Effects of hexaflumuron on phenoloxidase activity in Spodoptera litura (Fabricius) (Lepidoptera: Noctuidae). Acta Entomol. Sin. 5: 517-527.

Yeager J.F. \& Munson S.C. 1942: Changes induced in the blood cells of the southern armyworm, Prodenia eridania by the administration of poisons. J. Agric. Res. 64: 307-322.

Younes M.W.F., Abou El-Ela R.G. \& El-Mahasen M.E. 1999: Effect of certain insecticides on the haemocytes of the cotton leafworm, Spodoptera exigua (Lepidoptera: Noctuidae). $J$. Arab Biol. (A) 11: 425-457.

ZACHARY D., BREHÉLIN M. \& HofFmanN J.A. 1975: Role of the thrombocytoids in capsule formation in the dipteran Calliphora erythrocephala. Cell Tissue Res. 162: 142-348.

ZACHARY D. \& HoffMANn D. 1984: Lysozyme is stored in the granules of certain types in Locusta. J. Insect Physiol. 30: 405-411.

Zahedi M., Denham D.A. \& Ham P.J. 1992: Encapsulation and melanization of Armigeres subalbatus against inoculated sephadex beads. J. Invertebr. Pathol. 59: 258-263.

ZBINDEN L.C. 1987: A toxiclogist's view of immunotoxicology. In Berlin A., Dean J.H., Draper M.H., Smith M.B. \& Spreafico F. (eds): Immunotoxicology. Martinus Nijhoff, Dordecht, pp. 1-11.

Received November 21, 2011; revised and accepted February 9, 2012 